\title{
Sensitive Alpine Plant Communities to the Global Environmental Changes (Kazbegi Region, the Central Great Caucasus)
}

\author{
Otar Abdaladze ${ }^{1}$, Gia Nakhutsrishvili ${ }^{2}$, Ketevan Batsatsashvili ${ }^{1}$, Khatuna Gigauri ${ }^{1}$, \\ Tamar Jolokhava ${ }^{1}$, George Mikeladze ${ }^{2}$ \\ ${ }^{1}$ Alpine Ecosystems Research Program, Institute of Ecology, Ilia State University, Tbilisi, Georgia \\ ${ }^{2}$ Department of Plant Systematic, Institute of Botany, Ilia State University, Tbilisi, Georgia
}

Email address:

alpine_ecology@iliauni.edu.ge (O. Abdaladze)

To cite this article:

Otar Abdaladze, Gia Nakhutsrishvili, Ketevan Batsatsashvili, Khatuna Gigauri, Tamar Jolokhava, George Mikeladze. Sensitive Alpine Plant Communities to the Global Environmental Changes (Kazbegi Region, the Central Great Caucasus). American Journal of Environmental Protection. Special Issue: Applied Ecology: Problems, Innovations. Vol. 4, No. 3-1, 2015, pp. 93-100. doi: 10.11648/j.ajep.s.2015040301.25

\begin{abstract}
Sensitive plant communities are complexes of species particularly susceptible to global environmental changes (climate, land use, etc.). In the temperate zone alpine areas are considered as the most important "hot spots" in this respect. In the Central Great Caucasus, which is the traditional alpine vegetation monitoring site in the Caucasus, on the basis of 50-years long (1964-2014) phytosociological and ecological studies the most sensitive plant communities were distinguished: 1) Treeline ecotone communities, including: (a) Evergreen prostrate shrubbery dominated by Rhododendron caucasicum, (b) Dwarf semi-shrubbery dominated by Dryas caucasica and (c)Thermo-hygrophilous subalpine tall herbaceous vegetation dominated by Heracleum sosnowskyi; 2) Subalpine broad-leaved mesophilous meadows dominated by Anemonastrum fasciculatum, Geranium ruprechtii, Betonica macrantha and Trollius ranunculinus; 3) Alpine carpet-like meadows ("Alpine carpets") consist of Campanula biebersteiniana, Veronica gentianoides, Taraxacum porphyrantum, Sibbaldia semiglabra, etc.; 4) Snow-bed vegetation (Galanthus platyphyllus, Fritillaria latifolia, etc.), and 5) Subnival/nival vegetation patches formed by 2-5(7) species (Cerastium kasbek, Alopecurus dasyanthus, Tripleurospermum subnivale, Saxifraga sibirica, S. flagellaris, Delphinium caucasicum, Nepeta supina, Pseudovesicaria digitata, Symphyoloma graveolens, etc.). Totally habitats of these plant communities cover about $1 / 3$ of Kazbegi region area. Temperature rise, decrease in precipitation will lead to abrupt decrease of already small areas covered by Tertiary's relict tall herbaceous vegetation; elimination of a number of highly sensitive plant species including: relic, rare, endemic and critically endangered; disappearance of alpine snow-bed species. On account of early snow thawing or belated snowfall in autumn chionophyte plants (elfin, prostrate and dwarf shrubs and forbs in the alpine zone) sensitive to low moisture content, few and short-term snow cover and high temperature will lose. Probably sharp changes should be expected in subnival/nival zones, first of all, related to abrupt decrease in the glacier areas and subsequent increase in the distribution range of many species. According to the scenario suggested for the South Caucasus, which is based on predicted $3.9^{\circ} \mathrm{C}$ rise of temperature and decrease of precipitation by $9-13 \%$ during the century, it is expected that further climate warming may significantly change the vegetation and consequently the landscapes in the region. The vegetation may become similar to that of dry gorges of the Rocky Ridge of the Great Caucasus, which are situated 10-15 km to the north of the Kazbegi region.
\end{abstract}

Keywords: Caucasus, Climate Change, Sensitive Plant Communities, Alpine Plant Diversity

\section{Introduction}

The world climate continues steady warming. Global climate change and its ecological perspectives are the topical ecological problems of modernity [1]. The climate change effect will occur more or less in all ecosystems of the world, but most acute and rapid changes will expected in a highly sensitive alpine environment. The sensitivity of alpine species and plant communities are determined by low temperature conditions of alpine habitats [2-6]. Because of this, alpine environments of temperate zone are considered as the most important "hot spots" and alpine vegetation is viewed as the most noticeable bio-indicator [7-9]. Changing of low 
temperatures limiting effects will have a sharp impact on the diversity of alpine vegetation. Species vertical (along the altitudinal gradient) and horizontal (along the geographic sites) migrations will be the most prominent effect due to climate change $[10,11]$. As a result contemporary structure of vegetation, pattern of its spatial distribution formed during centuries will be disturbed, new plant communities will gradually develop, some species will disappear, and others will occupy new more or less suitable ecological niches. The mosaic structure of micro-relief in high mountains and hence highly heterogenous microclimate create diverse ecological niches, which will be very important for local plants to find shelters during vegetation transformation caused by climate change [12-14].

Sensitivity of alpine species is strongly dependend on plant living form, development rithm and other ecological peculiarities which determine vitality, competition, resistance, etc. $[2,9,15-18]$.
Expacted transformation of alpine vegetation threatens populations of species adapted to very specific ecological conditions; among such species are many rare, relict and endemic taxa. For this reason biodiversity degradation will become a real problem. These factors determine the importance of identification and ecological assessment of sensitive species and plant communities.

The goal of this study was to identify alpine species and plant communities sensitive to the global climate change in the Central Great Caucasus.

\section{Study Area \& Methods}

Studies were conducted in the Kazbegi region, which is

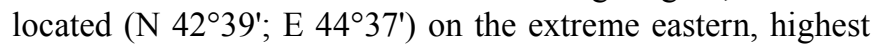
and geomorphologically the most complex central part of the Great Caucasus range (Fig. 1).

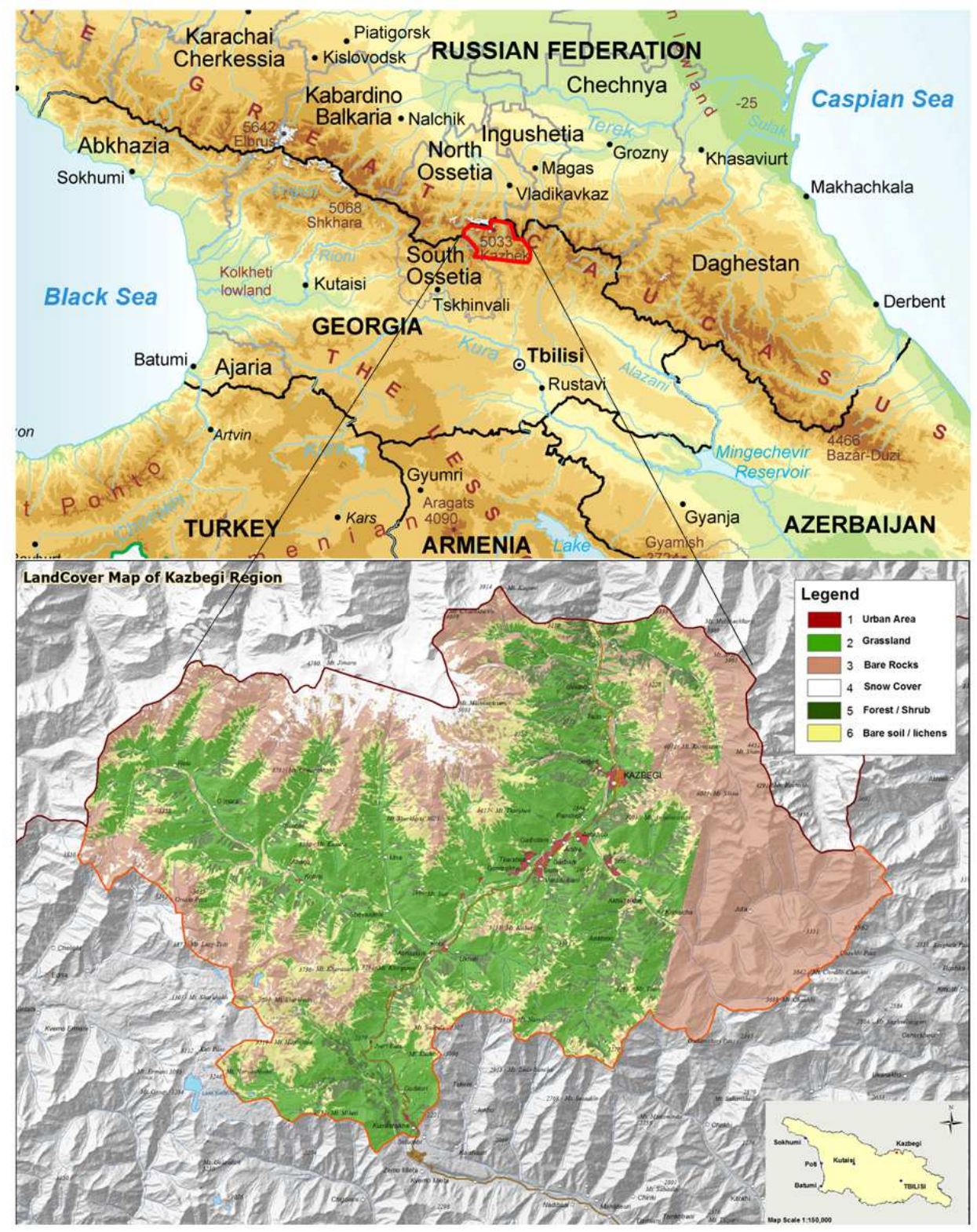

Figure 1. Location and main types of vegetation of the Kazbegi region (the Central Great Caucasus) 
The study area is of volcanic origin. Topography is formed by Jurassic rocks, Paleozoic and even older granites, younger lava and moraines. Mountain massifs of the Kazbegi volcanic area are overlain by Quaternary glacial or river deposits and rock falls as well as major accumulations of calcareous tuffs and travertines. Glacial deposits occur in many places. The relief of the Kazbegi region is formed by: ascending, bare, sharp ridges; isolated peaks; very steep rocky slopes; narrow gorges; and caves of erosion-tectonic origin. Ninety-nine big and small glaciers with different exposure and morphology are present in the region. The lowest, average and highest elevations of the region are $1210 \mathrm{~m}$ a.s.1., $2850 \mathrm{~m}$ a.s.l. and 5033 m a.s.l. (Mt. Kazbegi). Area of Kazbegi region is 1081.7 $\mathrm{km} 2[19,20]$. The dominant soil types are: leptic, folic, alumic, humic umbrisols [21].

The following factors determine the climate in the region: high elevations, complex topography, and location on north-facing macro-slope of the Great Caucasus. Tab. 1 represents some main characteristics of climate of the region. The climate type characteristic to upper forest-subalpine zones is moderately dry with short and cool summer and relatively cold winter. The climate type of subalpine-alpine zones is moderately moist, with short and cool summer and relatively dry and cold winter. The climate type of alpine-subnival zones is moderately dry and characterized by severe and long winter and absence of real summer. The climate type of subnival-nival zones is moderately moist, without summer and characterized by the permanent snow cover and ice [20,22].

The Kazbegi region is characterized by rich flora. It contains 1112 vascular plant species, which makes up 27\% of the total number of plants (about 4100 species; [23]) recorded in Georgia. The study area is characterized by a high richness of Caucasus endemic species (26\%) and genera (6 out of 11) $[18,24-27]$, as well as high diversity of plant communities [20, $28]$.

The altitudinal zonation of the vegetation is well pronounced. Mountain forest fragments, shrubberies, rock and scree vegetation is typical in the mountain-forest zone (up to
1800/1850 $\mathrm{m}$ a.s.1.). The alpine vegetation can be divided into four zones: subalpine (1800/1850-2450/2500 m a.s.l.), alpine (2450/2500-2950/3000 m a.s.l.), subnival (2950/3000-3650/3700 $\mathrm{m}$ a.s.1.) and nival (> $3700 \mathrm{~m}$ a.s.l.) $[18,20,22]$.

In the subalpine zone birch forests and elfin woodland (Betula litwinowii), shrub communities (Rhododendron caucasicum), herbaceous and tragacanthic (Astragalus denudatus) vegetation are typical remnants of natural vegetation types. However, vast grasslands, pastures and hay meadows characterized by e.g. Festuca ovina, F. varia subsp. woronowii, Hordeum violaceum, and Bromopsis variegata dominate in the subalpine landscape. The alpine zone is mainly characterized by grazed grasslands, which cover mountain ridges and south-facing steep slopes (dominated by Festuca varia subsp. woronowii), while the north-facing slopes are mainly covered with shrubs (Rhododendron caucasicum). Carpet-like meadows (where dicots mostly dominate), rock and scree vegetation are also well pronounced in the alpine zone. In the subnival zone vegetation is present as patches of few (2-5) species. In such micro-coenoses (nanocoenoses) cushion-like, dense-tussock and rosette life forms are predominate. In the nival zone only two species (Cerastium kasbek, Alopecurus dasyanthus) are recorded and they reach 4000 m a.s.1. [18, 20, 24, 25, 28]. In the Kazbegi region alpine vegetation is under long-term human impact [17].

Plant species were identified according to the following sources [29, 30]. Critical samples were compared with samples in the Herbarium of the Tbilisi Institute of Botany and with collection of Stephantsminda Alpine Ecology Institute of Ilia State University. Botanical nomenclature follows to [23, 30]. Phytosociological surveys have been carried out according to the cover-scale method [31, 32] during 1961-2014. The altitudinal differentiation of the vegetation as well as classification and nomenclature of plant communities are given according to [18]. ArcGIS Desktop version 9.3 (ESRI Inc., Redlands, CA) was used to calculate of areas covered by sensitive plant communities.

Table 1. Climate characteristics of the Kazbegi region (according to: Nakhutsrishvili, 2003; Nakhutsrishvili et al., 2005)

\begin{tabular}{|c|c|c|c|c|c|c|c|c|}
\hline \multirow[t]{2}{*}{$\begin{array}{l}\text { Vegetation zone/ } \\
\text { Alttude (m a.s.l.) }\end{array}$} & \multicolumn{2}{|c|}{$\begin{array}{l}\text { Temperature of } \\
\text { worm (July- } \\
\text { August) months } \\
\left({ }^{\circ} \mathrm{C}\right)\end{array}$} & \multicolumn{2}{|c|}{$\begin{array}{l}\text { Temperature of } \\
\text { cold (Janary- } \\
\text { February) } \\
\text { months }\left({ }^{\circ} \mathrm{C}\right)\end{array}$} & \multirow[t]{2}{*}{$\begin{array}{l}\text { Duration of } \\
\text { snow cover } \\
\text { (month) }\end{array}$} & \multirow[t]{2}{*}{$\begin{array}{l}\text { Max. depth } \\
\text { of snow cover } \\
\text { (cm) }\end{array}$} & \multirow{2}{*}{$\begin{array}{l}\text { Average } \\
\text { annual } \\
\text { presipitation } \\
(\mathbf{m m})\end{array}$} & \multirow[t]{2}{*}{ Other information } \\
\hline & Ave. & Max. & Min. & Ave. & & & & \\
\hline $\begin{array}{l}\text { Upper forest; } \\
\text { Subalpine/ } \\
1500-1900 \mathrm{~m}\end{array}$ & $14-18$ & 33 & -28 & -5 & $3-5$ & $\leq 80$ & $780-800$ & $\begin{array}{l}\text { In summer air humidity two times } \\
\text { higher than in winter; in August } \\
\text { number of clear, cloudless and hot } \\
\text { days are } 70 \% \text {; Drought is often }\end{array}$ \\
\hline $\begin{array}{l}\text { Subalpine; Alpine/ } \\
1900-2600 \mathrm{~m}\end{array}$ & $10-14$ & 33 & -30 & -11 & $5-7$ & $115-120$ & $1000-1500$ & $\begin{array}{l}\text { Number of fogy days: } 135 / \mathrm{yr} \text {; Winds } \\
\text { are often }\end{array}$ \\
\hline $\begin{array}{l}\text { Alpine; Subnival/ } \\
2600-3400 \mathrm{~m}\end{array}$ & 10 & 31 & -30 & -12 & $7-8$ & $\leq 200$ & $800-1000$ & $\begin{array}{l}\text { In summer morning frosts and winds } \\
\text { are often; Weather is strongly } \\
\text { change during a day }\end{array}$ \\
\hline $\begin{array}{l}\text { Subnival; Nival/ } \\
>3400 \mathrm{~m}\end{array}$ & 2.2 & 15 & -33 & -14 & 12 & $>200$ & $1000-1200$ & $\begin{array}{l}\text { Number of windstorms: } 12 / \text { month; } \\
\text { Number of snowy days: } 170 / \text { year }\end{array}$ \\
\hline
\end{tabular}




\section{Results \& Discussions}

In the alpine landscape of temperate mountains upper timberline is the most noticeable and well marked phenomenon. The treeline ecotone has various important ecological functions, such as: protection against avalanches, landslides, mud-flows, debris-flows and soil erosion; regulation of water balance in lowlands; creation of natural reservoir of clean water; maintenance high species diversity, etc. $[33,34]$. The treeline plant communities of the Kazbegi region are distinguished by exceptional diversity, which is expressed in the contrasting species composition and caused by various ecological conditions [22, 35]. High degree of species richness is mainly due to peculiar structural properties of plant communities, rather than ecological and human factors [28]. In the treeline ecotone of the Kazbegi region the following ecosystems should be referred to as highly sensitive: a) Evergreen prostrate shrubbery dominated by Rhododendron caucasicum; b) Dwarf semi-shrub community dominated by Dryas caucasica; c) Thermo-hygrophilous subalpine tall herbaceous vegetation (Megaphorbia); d) Subalpine broad-leaved meadows dominated by Anemonastrum fasciculatum, Trollyus ranunculinus, Geranium ruprechtii and Betonica macrantha.

The sensitivity of above mentioned plant communities is caused by: high slope degree (35-750), not well-formed and mobile soil cover, frequent solifluction, insignificant and/or short-term snow cover, etc. In Georgia droughts, high air and soil temperatures of the recent years [36] have particularly affected chionophils (Daphne glomerata, Rhododendron caucasicum, Vaccinium myrtillus, V. vitis-idaea, Empetrum caucasicum) widely presented on north-facing slopes in evergreen Rhododendron shrubbery. Withering of $R h$. caucasicum leaves and noticeable decline of Daphne glomerata are observed in the treeline ecotone. Some other factors also invoke the significant suppression of $R h$. caucasicum vitality. For example, after snowless winter in spring insufficient snow thaw rapidly at the edges of Rhododendron thickets and high solar radiation and warm air provoke photoinhibition and "winter drought" phenomena (Fig. 2; [16]). Mass withering of Rh. caucasicum will have strong negative impact on elfin shrubs and rare stenotopic herbs, which grow within the dense thickets in very specific ecological conditions. It will also break important facilitation relationships with main forest forming species in the region (Betula litwinowii). Dense thickets of $R h$. caucasicum promotes establishment of birch seedlings in the treeline ecotone [37, 38].

The area occupied by dwarf semi-shrub Dryas caucasica is not large and covers skeletal and stony calcareous soils on steep (20-500) slopes with North and North-West aspects between 2000-2600 $\mathrm{m}$ a.s.1.. Normally it grows on slopes with dense snow cover, often in the avalanche places. At present its area is significantly reduced. In the lower boundary of its distribution (2000-2200 m a.s.1.) only single and suppressed individuals can be found.

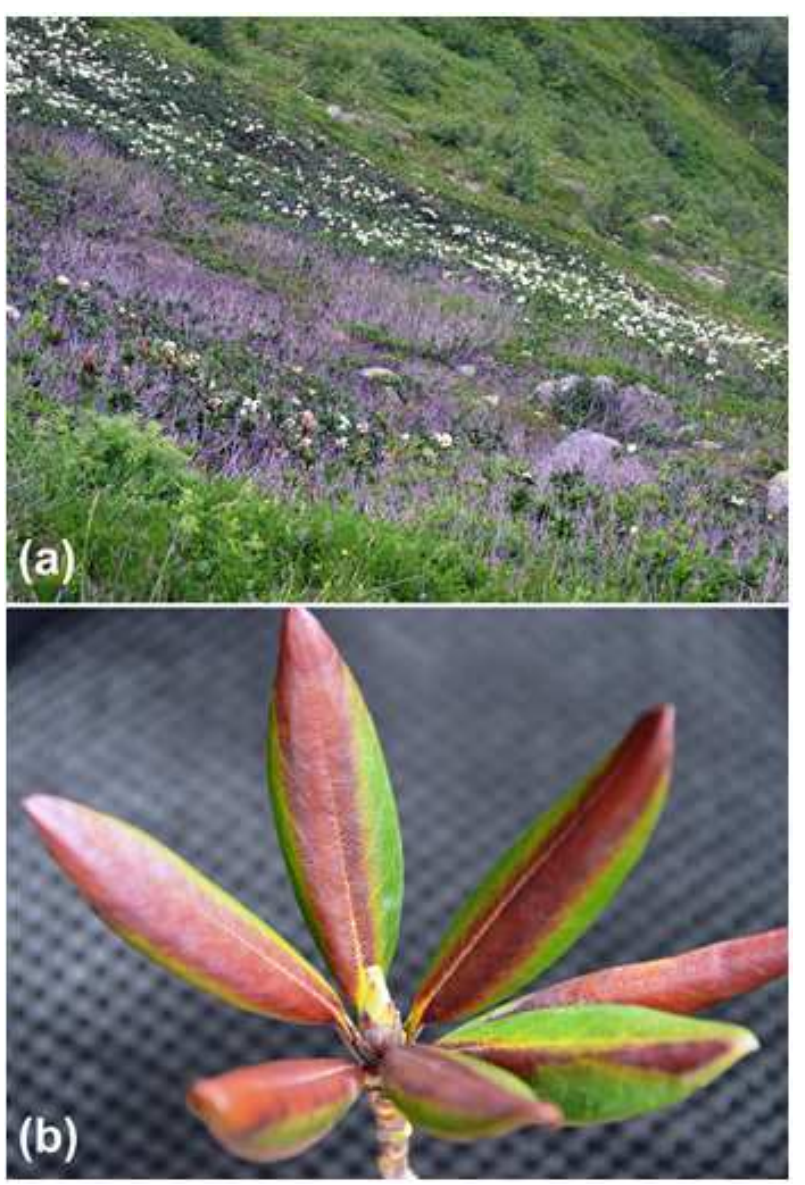

Figure 2. Damaged Rhododendron caucasicum thickets due to winter drought (a) and damaged leaves due to high insolation (b) in the treeline ecotone of the Kazbegi region

Our studies have shown, that the habitat of special natural phenomenon represented by stenotopic Tertiary relict thermo-hygrophilous subalpine tall herbaceous vegetation has a specific character: a) variable slope angle (between 1-20 and $600)$ and all available exposures; b) optimal air $\left(15-21^{\circ} \mathrm{C}\right)$ and soil $\left(10-14^{\circ} \mathrm{C}\right)$ temperatures without strong daily fluctuations; c) high level of soil moisture (33-62\%) and air humidity (58-89\%), including frequent horizontal precipitation (fog); d) low or moderate illumination $(800-1300 \quad \mu \mathrm{mol}$ photons $\left.\bullet \mathrm{m}^{-2} \cdot \mathrm{s}^{-1}\right)$; e) rich soils usually with near neutral $\mathrm{pH}$ (5-7), etc. This type of vegetation is composed of tall (1.8-2.5 $\mathrm{m}$, rarely $>3 \mathrm{~m}$ ) forbs (chiefly dicots) and grasses. They are characterized by rosetteless shoots, short top roots and rhizomes. Stratification is not observed in the canopy. Species richness of an individual community is not high (from 13 up to 33). Soil $\mathrm{pH}$ measurements revealed that tall herbaceous vegetation is confined to weak acid soils. It is known that in such type of soils humus horizon is well developed and mineralization is rather high [39]. It is also mentioned that the weak acid reaction of the soil helps to increase respiration of root system [40]. Soil temperature and moisture also influence $\mathrm{CO}_{2}$ output, although effect of these factors depends on vegetation type [41, 42]. Temperature increase may dry out 
soil upper layer, change soil $\mathrm{pH}$ and after certain time decrease mineralization rate. At the same time, if pool of nutrients will not correspond to excess $\mathrm{CO}_{2}$, flower and fruit development will decrease [16]. These processes may create some threats to tall herbaceous vegetation, which is strongly adapted to the certain environmental conditions. Tall herbaceous vegetation is one of the main bio-indicators for climate warming. It is very sensitive to the fluctuations of temperature and humidity. Recent droughts have had negative influence on the development of such species as: Senecio rhombifolius, $S$. propinquus, $S$. othonnae, Aconitum nasutum, A. orientale, Swertia iberica, Gadelia lactiflora, Dolychorhiza renifolia, Heracleum sosnowskyi, H. roseum, Cicerbita racemosa, Polemonium caucasicum, Delphinium flexuosum, Aquilegia caucasica, Asyneuma campanuloides, Doronicum macrophyllum, Inula helenium, I. magnifica, Lilium monadelphum subsp. georgicum, Valeriana tiliifolia, Cephalaria gigantea, Calamagrostis arundinacea, etc. Totally 85 tall herbaceous species are mentioned in the Central Caucasus [18]. In particular, plants will not grow properly; undeveloped inflorescence will be observed; flowers will be open permanently; early senescence and even complete wilting of leaves will occur [20,28].

Current climate warming will induce drastic changes in subalpine mesophilous broad-leaved meadows. Some of these meadows are associated with cool habitats above timberline, and some of them - with secondary meadows in the forest zone, on gentle or slightly sloping hillsides $\left(\leq 10^{\circ}\right)$ of both subalpine and alpine zones. Species composition in the plant communities will change due to soil drying, and populations of such species as: Anemonastrum fasciculatum, Trollyus ranunculinus, Geranium ruprechtii and Betonica macrantha will decline, or even some taxa will disappear.

Besides above mentioned sensitive treeline ecotone habitats there are some other ones as well. These are: a) Snow-bed patchy vegetation; b) "Alpine carpets" and c) Subnival plant communities. The snow-bed vegetation mostly occupies shady and wet cirques and small relief depressions with long-term snow cover and cool microclimate. These communities strongly depend on snowmelt water. Especially stress-dominated situations are observed in early spring flowering species (Galanthus platyphyllus, Fritillaria latifolia F. Lutea, Ficaria calthifolia, P. auriculata). For example, in the habitats of early spring geophyte $(G$. platyphyllus) the highest level of temperature and moisture stress probability was observed in the areas completely clear from snow cover, where plants are in the phase of fruiting. Individuals which start their flowering phase at the edges of snow-beds were in somewhat better hydro-thermal conditions than individuals in the snow cover.

Snow cover reduction caused by climate warming and early snowmelt will drastically change the ecological situation. Because of this the snow-bed plant communities could be considered as highly sensitive, as well as carpet-like alpine meadows ("Alpine carpets") occurimg in the upper part of the alpine zone. These small plant communities are found among large stones and moraines. They are predominantly composed of Campanula biebersteiniana, Veronica gentianoides, Taraxacum porphyrantum, Gnaphalium supinum, Sibbaldia semiglabra, Poa alpina, Pedicularis crassirostris. "Alpine carpets" which occur around the permanent snow spots and at the edges of glaciers contain the following species: Ranunculus oreophilus var. pumilus, R. baidarae, Primula algida, Gentiana djimilensis (= G. pyrenaica), G. angulosa, $G$. nivalis, Corydalis emanueli, Minuartia aizoides, Cerastium cerastoides, etc. "Alpine carpets" differ from true alpine meadows by their floristic composition and ecological peculiarities. Due to the lasting snow cover, they are characterized by short vegetative period. Herb cover does not exceed 3-4 cm, and $80 \%$ of aboveground phytomass is accumulated near the soil surface. Besides the climax "alpine carpets", secondary ones, enriched mainly by Alchemilla species, are present widely. Their development is caused by overgrazing. They occupy the most exploited alpine pastures $[18,22,28]$.

At the edge of alpine and subnival zone climatic and edaphic conditions become more severe and only few species are adapted to them $[1,4,6,15]$. In the Central Great Caucasus in the subnival zone vegetation is represented by individuals, or by small patches, which consist of 2-5(7) species. These are mostly cushion, trellis-like, tussock and rosette living form plants [26]. These plant ultra-microgroupings or micro-coenoses are determined as nanocoenoses [22]. The "hosting plants" of these nanocoenoses create microclimate, which use some other species [43,44] among which are many rare, relict and endemic plants [18, 25, 27]. The majority of subnival/nival species are chionophytes: they need deep and long-term snow cover for successful wintering. Probably sharp climatic changes in subnival/nival zones enforce plants to change habitats: move upwards, or even change slope aspect. During these processes a number of species might lose their habitats and completely disappear, populations of some others will be depressed and decreased, and vegetation patches will change their composition and areas.

A number of studies in the worldwide (GLORIA Project first monitoring cycle - 2001-2008) has shown that area of some alpine species, distribution character and vitality were changed due to of climate change [45]. According to these study vascular plant species number increased on 45 GLORIA target regions (especially in the boreal-to temperate mountains) and decreased on 10 summits. Such alteration is a result of warmer conditions; the combination of rising summer temperatures and stable to decreasing precipitation, which was recently documented for southern Europe for the past decades $[46,47]$. In the Central Great Caucasus GLORIA studies have shown insignificant increase in the abundance of resistant species individuals. This was recorded in parallel with an insignificant decrease in abundance of sensitive species. In subnival zone the changes are more visible, as a number of alpine species can be found at unusually high altitudes. In spite of this species migration processes from lower altitudes was not observed yet. Therefore, all of these changes must be considered as local fluctuations, and not as a succession phenomenon [48-52]. 
According to the scenario suggested for the South Caucasus and particularly the Central Great Caucasus which is based on predicted $3.9^{\circ} \mathrm{C}$ rise of temperature and precipitation decrease by $9-13 \%$ during a century [53], it is expected that further climate warming may significantly change the vegetation and consequently the landscapes in the region. Vegetation change models based on these data predict subalpine zone rise by 400-500 m. Subnival/nival zones will also rise by 500-600 m. This will be problematic to species occurring on plane areas at high elevation. These species are adapted to wintering under deep and long-term snow cover. It is doubtful that they can survive on steep slopes of the peaks. At the same time low competitiveness of subnival/nival plants may cause their suppression by expansion of subalpine and alpine plants. The worst predictions are plausible for such rare endemic species of monotypic genera as Symphyoloma graveolens and Pseudovesicaria digitata. The vegetation of Kazbegi region will resemble to that of dry gorges of the Rocky Ridge of the Great Caucasus, which are situated $10-15 \mathrm{~km}$ north of the Kazbegi region, in Russian Federation.

All above mentioned types of alpine vegetation are rather sensitive not only to the climate change, but also to damage by grazing, trampling and other human impacts $[17,18,20]$. Besides, they are characterized by low ability for natural recovery. The total area covered with habitats of sensitive plant communities is rather significant and reaches about $1 / 3$ of the Kazbegi region area (Fig. 3).

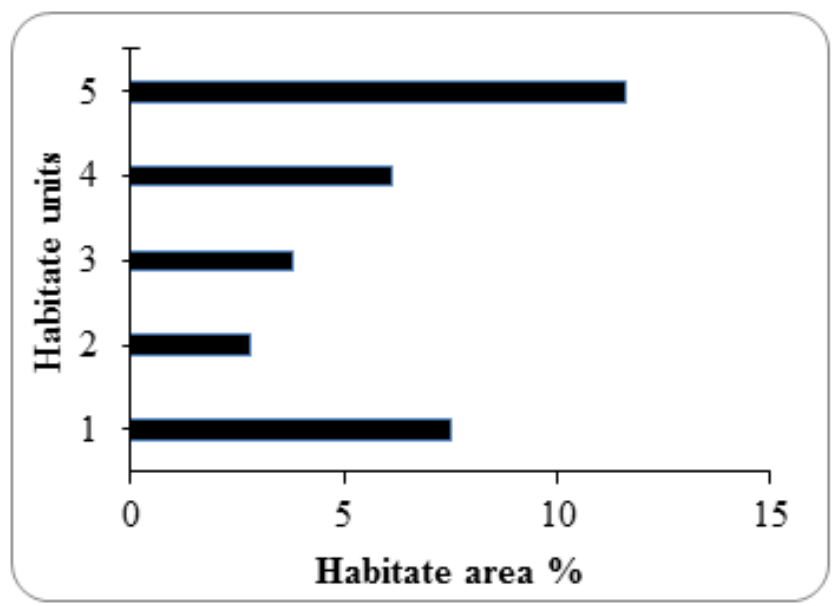

Figure 3. Proportion of sensitive plant community habitats from the total area of the Kazbegi region (1 - Rhododendretum caucasici and Betuletum litwinowii together; 2 - Dryetum caucasici; 3 - Broadleaf mesophilous meadows; 4 - Tall herbaceous vegetation and snowbed vegetation together; 5 - Subnival/Nival vegetation patches

Transformation of sensitive alpine vegetation due to of climate global worming will drastically change phytolandscapes in the Central Great Caucasus.

\section{Conclusions}

In the Kazbegi region (the Central Great Caucasus) on the basis of long-term phytosociological and ecological studies the most sensitive plant communities were distinguished: 1)
Alpine treeline ecotone communities: (a) Prostrate evergreen shrubbery dominated by Rhododendron caucasicum, (b) dwarf-shrub community dominated by Dryas caucasica; (c) Tertiary's relict thermo-hygrophilous subalpine tall herbaceous vegetation dominated by Heracleum sosnowskyi, Aconitum nasutum, Senecio rhombifolius, etc.; 2) Subalpine broad-leaved mesophilous meadows dominated by Anemonastrum fasciculatum, Trollyus ranunculinus, Geranium ruprechtii and Betonica macrantha; 3) Alpine carpet-like meadows ("Alpine carpets") represented by Campanula biebersteiniana, Veronica gentianoides, Corydalis emanueli, Taraxacum porphyrantum, Sibbaldia semiglabra, Poa alpina, etc.; 4)Snow-bed vegetation (Galanthus platyphyllus, Fritillaria latifolia, Primula auriculata); 5) Subnival/nival vegetation patches consist of few (2-5) species: Delphinium caucasicum, Cerastium kasbek, Saxifraga flagellaris, S. Sibirica, Alopecurus glacialis, A. Dasyanthus, Nepeta supina, Tripleurospermum subnivale, Pseudovesicaria digitata, Symphyoloma graveolens.

Further climate warming may significantly change the vegetation and consequently the phytolandscapes in the Central Great Caucasus.

\section{Aknowledgements}

The authors would like to thank all the people of Ilia State University and the Institute of Botany who helped in organizing the field work results of which are presented in this paper.

\section{References}

[1] Ch. Korner, "Mountain ecosystems in a changing environment", Eco. mont - Journal on Protected Mountain Areas Research, vol. 6, 2014, pp. 71-77.

[2] W. Larcher, K. Kainmuller, and J. Wagner, "Survival types of high mountain plants under extreme temperatures", Flora, 2008, pp. 1-22.

[3] Ch. Korner, "Mountain vegetation under environmental change", in R. Jandl, A. Borsdorf, H. van Miegroet, R. Lackner, R. Psenner, Eds. Alpine Space - Man and Environment. vol. 7: Global Change and Sustainable Development in Mountain Regions. Innsbruck Univ. Press, Innsbruck, 2009, pp. 25-30.

[4] Ch. Korner, "Alpine ecosystems", in S. A. Levin, Ed., Encyclopedia of Biodiversity, Elsevier, 2013, pp. 148-157.

[5] L. Nagy, and G. Grabherr, The Biology of Alpine Habitats, Oxford: Oxford University Press, 2009.

[6] W. Larcher, "Bioclimatic temperatures in the High Alps", in C. Lutz, Ed. Plants in Alpine Regions: Cell physiology of adaptation and survival strategies. Springer, 2012, pp. 21-27.

[7] G.. Grabherr, M. Gottfried, A. Gruber, and H. Pauli, "Patterns and current changes in alpine plant diversity", in F. S. Chapin, Ch. Korner, Eds. Arctic and Alpine Biodiversity: Patterns, Causes and Ecosystem Consequences. Springer, Berlin-Heidelberg-New York, 1995, pp. 167-181. 
[8] G.. Grabherr, M. Gottfried, and H. Pauli, "GLORIA: A Global Observation Research Initiative in Alpine environments", Mt. Res. Dev., 20, 2000, pp. 190-191.

[9] Ch. Korner, Alpine Plant Life: Functional Plant Ecology of High Mountain Ecosystems, Springer, Berlin-Heidelberg, 2003, $333 \mathrm{p}$.

[10] M. Gottfried, H. Pauli, K. Reiter, and G. Grabherr, "Potential effects of climate change on alpine and nival plants in the Alps", in: Ch. Korner, and E. M. Spehn, Eds., Mountain Biodiversity A Global Assessment, London-New York, Parthenon Publ., 2002.

[11] C. M. van de Ven, S. B. Weiss, and W. G. Ernst, "Plant species distributions under present conditions and forecasted for warmer climates in an arid mountain range”, Earth Interact. vol. 11, 2007, pp. 1-33.

[12] D. Scherrer, S. Schmid, and Ch. Korner, "Elevational species shifts in a warmer climate are overestimated when based on weather station data", Inter. J. of Biometeorology, vol. 55, 2010, pp. 645-654.

[13] D. Scherrer, and Ch. Korner, "Infra-red thermometry of alpine landscapes challenges climatic warming projections". Global Change Biology, vol. 16, 2010, pp. 2602-2613.

[14] D. Scherrer, and Ch. Korner, "Topographically controlled thermal-habitat differentiation buffers alpine plant diversity against climate warming". Journal of Biogeography, vol. 38, 2011, pp. 406-416.

[15] W. Larcher, "Klimastress im Gebirge - Adaptationstraining und Selektionsfilter fur Pflanzen", Rheinisch-Westf. Akad. Wiss. Vortr, vol. 291, 1980, pp. 49-78.

[16] W. Larcher, Physiological Plant Ecology: Ecophysiology and Stress Physiology of Functional Groups", Springer, Berlin-Heidelberg, 2003, 513 p.

[17] G.. Nakhutsrishvili, M. Akhalkati, and O. Abdaladze, "Main treats to the mountain biodiversity in Georgia (the Caucasus)", Mountain Forum Biull., IX, vol. 2, 2009, pp. 18-19.

[18] G.. Nakhutsrishvili, The Vegetation of Georgia (South Caucasus), Springer, Berlin-Heidelberg, 2013, 235 p.

[19] L. Maruashvili, Geomorphology of Georgia (Geoporfologya Gruzii), Metsniereba, Tbilisi, 1971, 346 p. (In Russian).

[20] G.. Nakhutsrishvili, O. Abdaladze, and A. Kikodze, Khevi: Kazbegi Region, Tbilisi, 2005, 54 p.

[21] World Reference Base for Soil Resources, "A framework for international classification, correlation and communication", Food \& Agriculture Organization of the UN, 2006, 128 p.

[22] G.. Nakhutsrishvili, "High- mountain vegetation of the Caucasus region", in L. Nagy, G. Grabherr, Ch. Korner, and D. B. A. E. Thompson, Eds., Alpine Biodiversity in Europe. Springer, Berlin-Heidelberg, 2003, pp. 93-103.

[23] R. Gagnidze, Vascular Plants of Georgia: A Nomenclatural Checklist, Universal, Tbilisi, 2005, 247 p.

[24] A. L. Kharadze, "On the subnival belt of the Greater Caucasus" (Subnivalnyi poias Bolshogo Kavkaza), Inst of Bot. Acad. of Science GSSR, vol. 25, 1965, pp. 103-104.

[25] M. F. Sakhokia, and E. Khutsishvili, (1975): Synopsis of the Flora of Higher Plants of Khevi”, Metsniereba, Tbilisi, 205p.
[26] G.. Nakhutsrishvili, and R. I. Gagnidze, "Die Subnivale und Nivale Hohgebirgsvegetation des Kaukasus", Phytocoenosis, vol. 11, 1999, pp. 173-182.

[27] G.. Schatz, T. Shulkina, and J. Solomon, Red List of Endemic Plants of the Caucasus Region, Saint Louis, MO, USA, Missouri Botanical Garden Press, 2013.

[28] G.. Nakhutsrishvili, O. Abdaladze, and M. Akhalkatsi, „Biotope types of the treeline of the Central Greater Caucasus“, in: D. Gafta, and J. Akeroyd, eds., Nature Conservation: Concepts and Practice, Springer, Berlin-Heidelberg, 2006, pp. 211-225.

[29] Identification Guide of Plants of Georgia (Sakartvelos Mtsenareta Sarkvevi), vol. I-II, Metsniereba, Tbilisi, 1964/1969. (in Georgian).

[30] Flora of Georgia (Sakartvelos Flora), v. I-XII, Metsniereba, Tbilisi, 1971-2013 (in Georgian).

[31] J. Braun-Blanquet, Pflanzensoziologie. Grundzuge der Vegetationskunde. 3. Aufl. Springer, Wien, 1964.

[32] E. van der Maarel, "Transformation of cover-abundance values for appropriate numerical treatment - alternatives to the proposals by Podani”, J. Veg. Sci. vol. 18, 2007, pp. 767-770.

[33] Ch. Korner, "A re-assessment of high elevation treeline positions and their explanation". Oecologia. vol. 115, 1998, pp. 445-459.

[34] Ch. Korner, Alpine Treelines: Functional Ecology of the Global High Elevation Tree Limits, Springer, Heidelberg, 2012, 220 p.

[35] A. G. Dolukhanov, "Timberline and subalpine belt in Caucasus mountains, USSR". Alpine Arctic Research, vol. 10, 1978, pp. 409-422.

[36] E. S. Elizbarashvili, T. F. Urushadze, M. E. Elizbarashvili, S. E. Elizbarashvili, and M. K. Schaefer, "Temperature regime of some soil types in Georgia", Eurasian Soil Sci. vol. 43, 2010, pp. $427-435$.

[37] M. Akhalkatsi, O. Abdaladze, G. Nakhutsrishvili, and W. K. Smith, „Facilitation of seedling microsites by Rhododendron caucasicum extends the Betula litwinowii alpine treeline, Caucasus mountains, Republic of Georgia“, Arctic Antarctic Alpine Research, vol. 38, no. 4, 2006, pp. 481-488.

[38] N. M. Hughes, D. M. Johnson, M. Akhalkatsi, and O. Abdaladze, "Characterizing Betula litwinowii seedling microsites at the alpine-treeline ecotone, Central Greater Caucasus mountains, Georgia", Arctic Antarctic Alpine Research, vol. 41 (1), 2009, pp. 112-118.

[39] T. F. Urushadze, (1997): Basic Soils of Georgia (Sakartvelos Dziritadi Niadagebi), Metsniereba, Tbilisi (in Georgian).

[40] S. Reth, M. Reichstein, and E. Falge, "The effect of soil water content, soil temperature, soil $\mathrm{pH}$-value and the root mass on soil CO2 efflux - A modified model”, Plant \& Soil., vol. 268, 2005, pp. 21-33.

[41] X. F. Wen, G. R. Yu, X. M. Sun, Q. K. Li, Y. F. Liu et al., "Soil moisture effect on the temperature dependence of ecosystem respiration in a subtropical Pinus plantation of Southeastern China”. Agric for Meteorol. Vol. 137, 2006, pp. 166-175.

[42] W. Y. Kao, and K. W. Chang, "Soil CO2 efflux from a mountainous forest-grassland ecosystem in central Taiwan". Botanical Studies, vol. 50, 2009, pp. 337-342. 
[43] Z. J. Kikvidze, and G. Nakhutsrishvili, "Facilitation in the subnival vegetation patches". J. Veg. Sci., vol. 9, 1998, pp. 222-226.

[44] R. M. Callaway, R. W. Brooker, P. Choler, Z. J. Kikvidze, Ch. J. Lortie et al., "Positive interactions among alpine plants increase with stress". Nature, vol. 417, 2002, pp. 844-848.

[45] H. Pauli, M. Gottfried, S. Dullinger, O. Abdaladze, M. Akhalkatsi et al., "Recent plant diversity changes on Europe's mountain summits". Science, vol. 336, no. 6070, 2012, pp. 353-355.

[46] A. Mariotti, N. Zeng, J. H. Yoon, V. Artale, A. Navara et al., "Mediterranean water cycle changes: transition to drier 21st century conditions in observations and CMIP3 simulation", Environm. Res. Lett. Vol.3, 2008, 044001. (doi:10.1088/1748-9326/3/4/044001).

[47] S. Del Rio, L. Herrero, R. Fraile, A. Penas, "Spatial distribution of recent rainfall trends in Spain (1961- 2006)", Int. J. Climatol., vol. 31, 2011, pp. 656-667.

[48] Kh. Gigauri, M. Akhalkatsi, G. Nakhutsrishvili, O. Abdaladze, "First Signs of weak thermophilisation on the GLORIA-EUROPE Target Region in the Central Caucasus GE-SAK)", (Termopilizaciis Pirveli Sustad Gamokhatuli Nishnebi Centraluri Kavkasionis GLORIA-EUROPE-is Samonitoringo Qselis Sakvlev Mtsvervalebze - GE-SAK), in G. Nakhutsrishvili, ed., Biodiversity of Georgia. Tbilisi, Georg. Nat. Acad. of Sci. Publ, 2011, pp. 19-22 (in Georgian with English summary).
[49] Kh. Gigauri, M. Akhalkatsi, G. Nakhutsrishvili, O. Abdaladze, "Monitoring of vascular plant diversity in a changing climate in the alpine zone of the Central Greater Caucasus", Turk. J. Bot., vol. 37(6), 2013, pp. 1104-1114.

[50] Kh. Gigauri, O. Abdaladze, G. Nakhutsrishvili, M. Akhalkatsi (2014): „Vascular plant diversity and climate change in the alpine zone of the Central Greater Caucasus", International Journal of Ecosystems and Ecology Science. Vol. 4 (4), 2014, pp. 573-589.

[51] B. Erschbamer, M. Mallaun, P. Unterluggauer, O. Abdaladze, M. Akhalkatsi M et al., (2010): "Plant diversity along altitudinal gradients in the Central Alps (South Tyrol, Italy) and in the Central Greater Caucasus (Kazbegi Region, Georgia)", Tuexenia, vol. 30, 2010, pp. 11-29.

[52] B. Erschbamer, M. Mallaun, P. Unterlugauer, G. Nakhutsrishvili G, M. Akhalkatsi M et al., „Plant diversity along altitudinal gradients in the Central Alps and in the Central Caucasus: the project GLORIA in south Tyrol (Italy) and in the Kazbegi region (Georgia)", in F. Pedrotti, ed., Colloques Phytosociologiques, XXIX, Camerino, Italy, 2013, pp. 167-188.

[53] Georgia's Second National Communication Under the UN Framework Convention on Climate Change", Tbilisi, 2009, $230 \mathrm{p}$. 